\title{
MENINGKATKAN KEMAMPUAN BERBICARA MAHASISWA DENGAN PLATFORM LEARNSOCIAL
}

\author{
Megawati $^{1(*)}$, Eka Rista Harimurti ${ }^{2}$, Ivon Mukaddamah ${ }^{3}$ \\ STKIP Kusuma Negara, Indonesia \\ Megawati86@stkipkusumanegara.ac.id ${ }^{1}$, Ekaristaharimurti@ stkipkusumanegara.ac.id², \\ ivon@stkipkusumanegara.ac.id ${ }^{3}$
}

Received: 05 Agustus 2020

Revised: 13 Agustus 2020

Accepted: 02 September 2020

\begin{abstract}
Learnsocial merupakan sejenis platform yang berfungsi sebagai media dalam pembelajaran yang membantu dosen ataupun guru dalam menyampaikan materi. Materi yang telah disampaikan dikelas dapat diulas kembali oleh mahasiswa dengan menggunakan platform learnsocial. Mahasiswa dapat mempelajari materi yang telah diberikan dosen dimana saja, karena platform learnsocial dapat diakses menggunakan handphone, laptop atau komputer. Dalam keadaan offline mahasiswa tetap dapat mengakses materi yang telah didownload tetapi untuk mendengarkan native speaker dibutuhkan jaringan internet yang baik. Penelitian ini dilakukan kepada mahasiswa semester dua Prodi Pendidikan Bahasa Inggris STKIP Kusuma Negara. Penelitian ini menggunakan metode Classroom Action Research atau penelitian tindakan kelas yang terdiri dari dua siklus. Pada siklus pertama didapatkan hasil 45\% mahasiswa yang sudah tuntas dalam pembelajaran kemampuan berbicara bahasa Inggris dengan rata-rata nilai mahasiswa sebesar 71,3. Pada siklus kedua didapatkan hasil $90 \%$ mahasiswa dengan kemampuan berbicara dengan rata-rata nilai sebesar 88,5 yang artinya $90 \%$ mahasiswa tuntas dapat menggunakan platform learnsocial dalam kemampuan berbicara. Platform learnsocial mudah digunakan mahasiswa dan dosen. Platform tersebut dapat meningkatkan kemampuan mahasiswa dalam berbicara bahasa Inggris. Hal tersebut terbukti dengan ketuntasan dalam kemampuan berbicara pada siklus I dan siklus II. Platform learnsocial efektif digunakan dalam pembelajaran selain ramah lingkungan juga mudah digunakan.
\end{abstract}

Keywords: Kemampuan berbicara; Platform learnsocial

(*) Corresponding Author: Megawati, Megawati86@stkipkusumanegara.ac.id, 081285961641

How to Cite: Megawati, Harimurti, E. R., \& Mukaddamah, I. (2020). Meningkatkan Kemampuan Berbicara Mahasiswa Dengan Platform Learnsocial. Research and Development Journal of Education, 1(1), 23-32.

\section{INTRODUCTION}

Perkembangan teknologi di era 4.0 yang akan menuju era 5.0 menuntut para generasi muda berpacu dalam memahami penggunaan teknologi. Hal ini bertujuan agar kita sebagai generasi tidak telat informasi dan selalu aktual menerima segala macam berita yang masuk. Berbagai macam media dalam menyampaikan informasi diantaranya adalah media cetak, media elektronik, serta media dalam bentuk digital. Perkembangan yang pesat bila tidak diimbangi dengan kemampuan sumber daya manusia maka tidak akan berjalan dengan baik sehingga informasi yang didapat tidak dapat disampaikan dengan baik ke orang lain.

Dalam penyampaian informasi dapat berupa tulisan, suara ataupun keduanya. Manusia dapat menyampaikan informasi kepada orang lain dengan berbicara dan dapat juga berupa teks tulisan. Menurut Sadiman (2008:17-18) menjelaskan dengan adanya 
media maka pesan yang disampaikan tidak terlalu bersifat verbalistis, kemudian dapat memberikan rangsangan, pengalaman, persepsi siswa, dapat mengatasai keterbatasan ruang, waktu dan daya indera. Dengan adanya media maka dapat membatu proses penyampaian informasi dari narasumber kepada penerima pesan. Menurut Megawati (2017: 108) Media merupakan salah satu komponen komunikasi yaitu sebagai pembawa pesan dari komunikator menuju komunikan. Berbagai macam media dapat digunakan untuk berkomunikasi dengan berbicara.

Berbicara merupakan suatu kemampuan dasar dalam berbahasa Inggris. Menurut Kariani (2016: 63) Dalam kehidupan sehari-hari kita lebih sering berkomunikasi dengan berbicara. Komunikasi akan lebih efektif apabila dilakukan dengan berbicara. Menurut Duilan (2017:13) berbicara berarti menyampaikan ide gagasan atau pesan lisan secara efektif melalui lambang-lambang bunyi agar terjadi kegiatan komunikasi antara penutur dan mitra tutur. Dalam berbicara kita mengungkapkan suatu makna dapat berupa ujaran kepada orang lain agar orang lain memahami apa yang kita ungkapkan. Menurut Alex ((2017:36) berbicara adalah aktifitas menuangkan fikiran kepada orang lain. Dalam artian berbicara merupakan sebuah kegiatan atau tindakan memberikan ungkapan apa yang ada dalam hati dan fikiran kepada orang lain sehingga orang yang di ajak bicara memahmi maksud yang orang yang berbicara. Namun dalam berbicara muncul beberapa kendala, apalagi terkait dengan kemampuan berbicara bahasa Inggris. Dengan demikian dilakukan penelitian yang bertujuan untuk mengetahui kemampuan berbicara mahasiswa dengan menggunakan platform learnsocial. Prodi pendidikan bahasa Inggris STKIP Kusuma Negara menggunakan media sejenis platform learnsocial untuk memudahkan dalam memberikan latihan-latihan atau pengayaan dalam skill dasar bahasa Inggris. Tujuan dari pemberian latihan-latihan bahasa Inggris adalah agar mahasiswa dapat belajar secara dengan platform tersebut.

Mahasiswa merasa malu ketika harus berbicara bahasa inggris didepan orang lain karena mereka memiliki keterbatasan kosakata bahasa Inggris, dengan alasan mereka tidak hafal structure dan grammar, padahal di dalam kemampan berbicara bahasa Inggris terdapat unsur lain yang tidak kalah pentingnya. Ketika pembelajaran di kelas, mahasiswa kurang memahami apa yang disampaikan dosen dan mereka tidak dapat mengulas pembelajaran di rumah. Menghadapi kendala tersebut, dosen melakukan terobosan dengan menggunakan media sejenis platform yang menggunakan jaringan internet. Menurut Kenji KItao dalam Munir (2010:196) internet dimanfaatkan dalam kehidupan sehari-hari yaitu sebagai alat komunikasi, mengakses informasi, pendidikan dan pembelajaran. Dalam pembelajaran, salah satunya adalah menggunakan platform learnsocial yang membutuhkan jaringan internet. Menurut Megawati (2020: 51) Platform learn social merupakan sejenis media yang setiap mahasiswa dapat mengasah keterampilan berbahasa Inggris dengan mengerjakan latihan-latihan yang terdapat pada platform tersebut. Penggunaan platform learnsocial sangatlah mudah dengan menggunakan handphone, laptop ataupun komputer. Dosen menggunakan platform learnscocial karena platform tersebut tepat dan mudah digunakan bagi mahasiswa dan juga dosen. Meskipun dalam pelaksanaannya terjadi kekurangan karena tidak ada media pembelajaran yang sempurna, dan selau ada kelemahannya.

Platform learnsocial digunakan untuk melatih kemampuan berbicara bahasa Inggris. Agar mahasiswa memiliki kemampuan berbahasa Inggris yang baik maka mereka harus banyak latihan berbicara sehingga kemampuan berbicaranya dapat berkembang dan tumbuh rasa percaya diri ketika berbicara bahasa Inggris di depan orang. Namun untuk mendapatkan kemampuan bahasa Inggris yang baik, dibutuhkan beberapa unsur yang dapat menjadikan kemampuan bahasa Inggris tersebut dikatakan baik.

Menurut Brown (2004:172) terdapat 5 unsur elemen yang dijadikan indikator dalam penilaian berbicara bahasa Inggris yaitu: 
1. Grammar merupakan susunan tata bahasa atau pola dalam bahasa Inggris. Susunan kalimat yang memilik grammar tidak tepat maka maknanya pun akan berbeda. Karena dalam bahasa Inggris pola kalimat mengikuti aturan waktu, kapan terjadinya.

2. Pronunciation merupakan aksen ucapan yang diucapkan oleh pembicara. Dalam hal ini apabila kata yang diucapkan tidak tepat meski maknanya sama maka artinya pun akan berbeda apabila di dengar oleh pendengar. Sehingga dapat menimbulkan salah penafsiran. Apakah makna yang simaksud tunggal atau jamak, serta tebal dan tipis ini sngat berpengaruh terhadap isi dari makna tersebut.

3. Vocabulary merupakan kosakata atau kata-kata yang digunakan dalam berbicara. Apakah pembicara menggunakan kosakata sehari-hari ataukah kosakata yang jarang didengar dan sulit dipahami.

4. Fluency merupakan kecakapan dalam berbicara yang berarti, ke fasihan seseorang ketika berbicara bahasa Inggris. Apakah terbata-bata atau lancar dalam berbicara. Ketika pembicara bahasa inggris fasih berbicara maka pendengar akan mudah untuk mencerna pesan yang diucapkan. Apabila pembicara sulit atau lamban berbicara, ini mentulitkan pendengar untuk memahami hal apa yang ingin disampaikan.

5. Comprehension yang artinya pemahaman. Ketika seseorang berbicara bahasa Inggris maka harus dapat dipahami oleh orang lain. Apabila yang disampaikan pembicara tidak dapat dipahami maka tidak akan terjadi komunikasi. Hal ini akan mengurangi kemampuan berbicarra bahasa Inggris yang baik.

\section{METHODS}

Penelitian tersebut dilakukan kepada mahasiswa semester dua Prodi Pendidikan Bahasa Inggris. Populasi mahasiswa semester dua Prodi Pendidikan Bahasa Inggris terdiri dari 2 kelas yaitu mahasiswa kelas karyawan dan mahasiswa kelas reguler. Namun yang dipakai untuk penelitian hanya satu kelas yaitu mahasiswa reguler pagi. Sampel dalam penelitian berjumlah 20 mahasiswa. Metode penelitian tersebut adalah Classroom Action Research atau penelitian tindakan kelas yang terdiri dari dua siklus (Saputra \& Prasetyono, 2020). Setiap siklus terdiri atas perencanaan (Planning), tindakan (Acting), pengamatan (Observing) dan perencanaan ulang (Reflecting) yang digunakan dalam penelitian eksperimen penelitian tindakan kelas (Ramdayana, Prasetyono \& Rahman, 2020).

\section{Siklus 1}

Pada siklus pertama tahap perencanaan dosen menyiapkan materi pembelajaran speaking sesuai dengan silabus, kemudian dosen mengabsen kehadiran mahasiswa dan menyampaikan informasi terkait platform learnsocial. Pada tahap tindakan dosen meminta mahasiswa untuk melakukan monolog, mahasiswa diminta menceritakan pengalaman pribadi yang menyenangkan atau pengalaman pribadi yang tidak menyenangkan minimal tujuh menit. Mahasiswa diharapkan dapat berbicara bahasa inggris dengan aktif, mereka diharapkan dapat menggunakan kosakata atau frase yang mudah untuk di mengerti baik oleh pendengar ataupun dirinya sendiri. Kemudian tahap pengamatan, pada tahap ini dosen mengamati kemampuan berbicara mahasiswa serta memberikan penilaian dan saran atas kekurangan kemampuan berbicara mahasiswa.

Ada beberapa kriteria pada kualifikasi skor, yaitu Baik sekali $=4$, Baik $=3$, Cukup $=2$, Kurang $=1$. Hasil pengamatan dapat dilihat pada tabel berikut ini. 
Tabel 1.

Hasil Pengamatan Dosen Terhadap Mahasiswa Pada Siklus 1

\begin{tabular}{|c|c|c|c|c|c|}
\hline \multirow[t]{2}{*}{ No. } & \multirow[t]{2}{*}{ Aspek yang diobservasi } & \multicolumn{4}{|c|}{ Skor } \\
\hline & & 1 & 2 & 3 & 4 \\
\hline 1 & $\begin{array}{l}\text { Mahasiswa tidak menggunakan bahasa } \\
\text { Indonesia }\end{array}$ & & $\sqrt{ }$ & & \\
\hline 2 & Mahasiswa berani mengemukakan pendapat & $\sqrt{ }$ & & & \\
\hline 3 & $\begin{array}{l}\text { Mahasiswa mengajukan pertanyaan kepada } \\
\text { dosen }\end{array}$ & & $\sqrt{ }$ & & \\
\hline 4 & $\begin{array}{l}\text { Mahasiswa memahami penjelasan dosen } \\
\text { terkait platform learnsocial }\end{array}$ & & $\sqrt{ }$ & & \\
\hline 5 & $\begin{array}{l}\text { Mahasiswa berusaha berbicara dengan } \\
\text { bahasa Inggris }\end{array}$ & & $\sqrt{ }$ & & \\
\hline 6 & $\begin{array}{l}\text { Mahasiswa menggunakan kosakata yang } \\
\text { baru }\end{array}$ & & $\sqrt{ }$ & & \\
\hline 7 & $\begin{array}{l}\text { Mahasiswa mampu memberikan ide dengan } \\
\text { topik yang berbeda }\end{array}$ & & $\sqrt{ }$ & & \\
\hline & $\begin{aligned} \text { Jumlah }\end{aligned}$ & 1 & 12 & & \\
\hline & Total Skor & & 13 & & \\
\hline & Rata-rata & 1,85 & & & \\
\hline
\end{tabular}

Sumber : Peneliti

Lalu tahap perencanaan ulang atau refleksi yang berarti dosen melihat kembali kekurangan dan kelebihan dalam pembelajaran dengan platform learnsocial. Tahap ini didapatkan hasil sebesar 9/20 x $100 \%=45 \%$ mahasiswa yang tuntas dalam kemampuan berbicara sedangkan yang tidak tuntas didapatkan hasil 11/20x 100\% $=55$ $\%$ mahasiswa tidak tuntas dalam pembelajaran berbicara menggunakan platform learnsocial. Dosen melakukan evaluasi sejauh mana platform learnsocial dapat menjadi media pembelajaran yang dapat membantu dosen dalam penyampaian materi.

\section{Kemampuan Berbicara Bahasa Inggris}

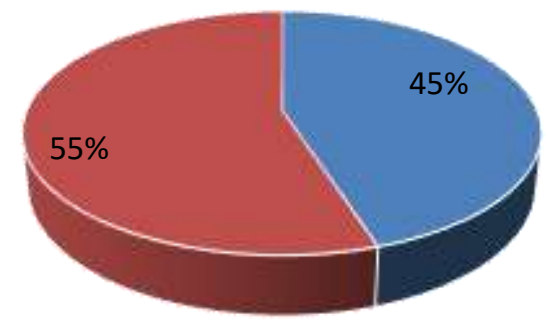

- Tuntas - Tidak tuntas

Sumber : Peneliti

Diagram 1.

ketuntasan kemampuan berbicara Siklus I

Berdasarkan nilai evalusi siklus I didapatkan rata-rata nilai 71.3, sebanyak 11 mahasiswa tidak tuntas dalam pembelajaran berbicara, sedangkan 9 mahasiswa tuntas dalam pembelajaran. 
Tabel 2.

Distribusi Frekuensi Siklus I

\begin{tabular}{clc}
\hline No. & Rentang nilai & Jumlah responden \\
\hline 1 & $60-64$ & 4 \\
2 & $65-69$ & 8 \\
3 & $70-74$ & 4 \\
4 & $75-79$ & 3 \\
5 & $80-84$ & 1 \\
& Rata-rata nilai & 71.3 \\
\hline
\end{tabular}

\section{Siklus II}

Sumber : Peneliti

Pada siklus kedua, tahap perencanaan (planning) mahasiswa sudah lebih memahami penggunaan platform learnsocial sehingga dosen tidak perlu mengulas dari awal cara mengaksesnya. Kemudian tahap tindakan, dosen meminta mahasiswa untuk bercerita mengenai impian dan cita-cita yang ingin diwujudkan setelah mereka lulus sarjana. Dosen memberikan durasi waktu minimal tujuh menit dalam merekam suara dan menyimpannya dalam platform learnsocial. Kemudian tahap pengamatan, dosen memeriksa kemampuan berbicara mahasiswa serta memberikan arahan mengenai pronunciation yang tidak tepat.

Ada beberapa kriteria pada kualifikasi skor, yaitu Baik sekali $=4$, Baik $=3$, Cukup $=2$, Kurang $=1$. Hasil pengamatan dapat dilihat pada tabel berikut ini.

Tabel 3.

Hasil Pengamatan Dosen Terhadap Mahasiswa Pada Siklus 2

\begin{tabular}{|c|c|c|c|c|c|}
\hline \multirow[t]{2}{*}{ No. } & \multirow[t]{2}{*}{ Aspek yang diobservasi } & \multicolumn{4}{|c|}{ Skor } \\
\hline & & 1 & 2 & 3 & 4 \\
\hline 1 & $\begin{array}{l}\text { Mahasiswa tidak menggunakan bahasa } \\
\text { Indonesia }\end{array}$ & & & $\sqrt{ }$ & \\
\hline 2 & Mahasiswa berani mengemukakan pendapat & & & & $\sqrt{ }$ \\
\hline 3 & $\begin{array}{l}\text { Mahasiswa mengajukan pertanyaan kepada } \\
\text { dosen }\end{array}$ & & & V & \\
\hline 4 & $\begin{array}{l}\text { Mahasiswa memahami penjelasan dosen } \\
\text { terkait platform learnsocial }\end{array}$ & & & & $\sqrt{ }$ \\
\hline 5 & $\begin{array}{l}\text { Mahasiswa berusaha berbicara dengan } \\
\text { bahasa Inggris }\end{array}$ & & & & $\sqrt{ }$ \\
\hline 6 & $\begin{array}{l}\text { Mahasiswa menggunakan kosakata yang } \\
\text { baru }\end{array}$ & & & $\sqrt{ }$ & \\
\hline 7 & $\begin{array}{l}\text { Mahasiswa mampu memberikan ide dengan } \\
\text { topik yang berbeda }\end{array}$ & & & V & \\
\hline & Jumlah & & & 12 & 12 \\
\hline & Total Skor & & 24 & & \\
\hline & Rata-rata & & 3,42 & & \\
\hline
\end{tabular}

Sumber : Peneliti

Pada tahap perencanaan ulang, dosen mengevaluasi kemampuan berbicara mahasiswa didapatkan hasil sebesar 18/20 x 100\% $=90 \%$. Mahasiswa dapat mentuntaskan pembelajaran yang telah diberikan dosen. Sedangkan mahasiswa yang tidak tuntas dalam pembelajaran $2 / 20 \times 100 \%=10 \%$. Dengan nilai ratarata (score) adalah 88.5. 


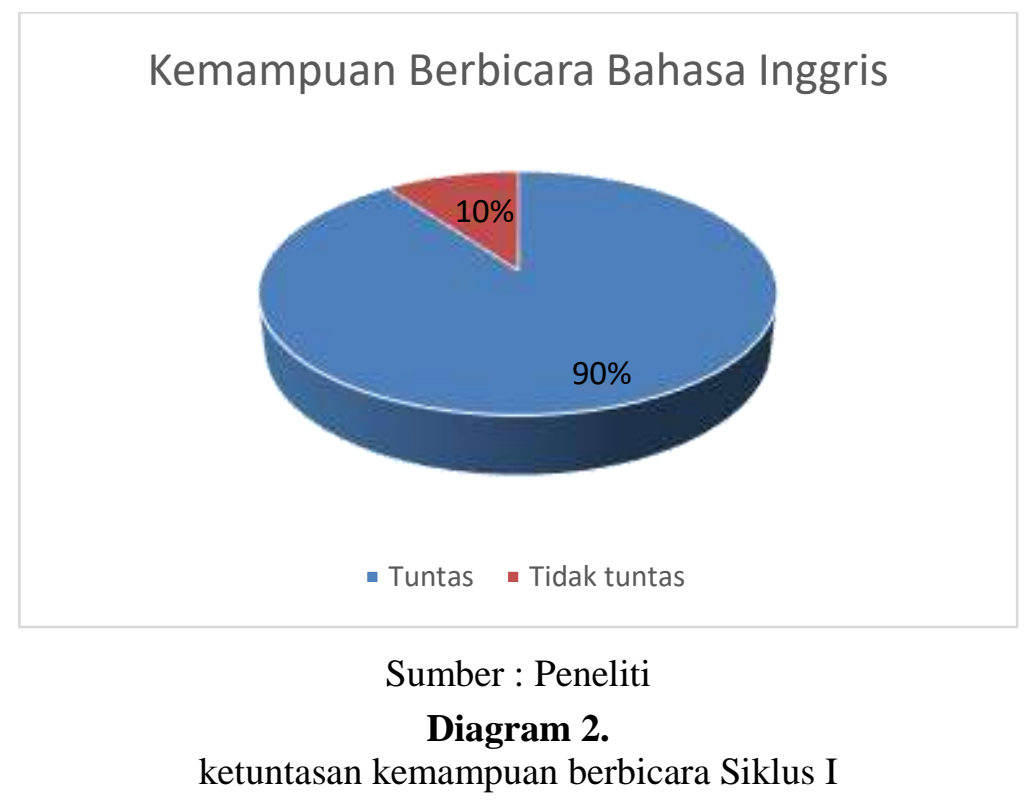

Berdasarkan nilai evalusi siklus II didapatkan rata-rata nilai 88.5 , sebanyak 2 mahasiswa tidak tuntas dalam pembelajaran berbicara, sedangkan 18 mahasiswa tuntas dalam pembelajaran.

\section{Tabel 4.}

Distribusi Frekuensi Siklus I

\begin{tabular}{clc}
\hline No. & Rentang nilai & Jumlah responden \\
\hline 1 & $60-64$ & 1 \\
2 & $65-69$ & 1 \\
3 & $70-74$ & 4 \\
4 & $75-79$ & 8 \\
5 & $80-84$ & 6 \\
& Rata-rata nilai & 88.5 \\
\hline
\end{tabular}

Sumber : Peneliti

\section{RESULTS \& DISCUSSION}

Setelah dosen melakukan Siklus I dan Siklus II maka dilakukan evaluasi yang diperoleh rata-rata nilai (score) seperti diagram di bawah ini :

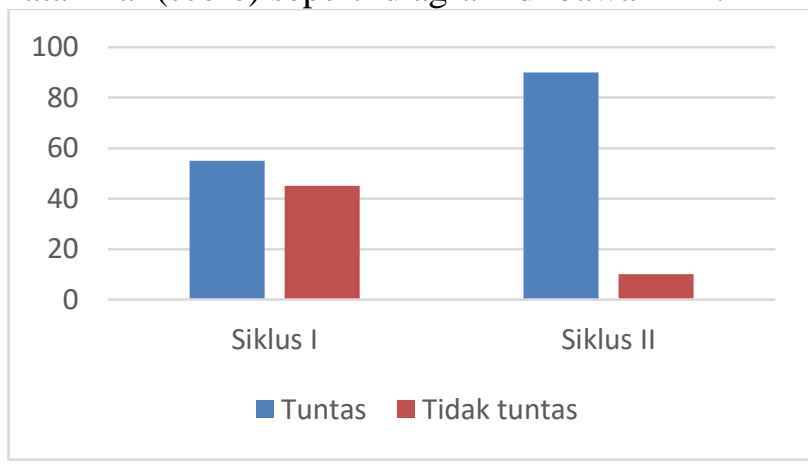

Sumber : Peneliti

Diagram 3.

Persentase ketuntasan mahasiswa dalam kemampuan berbicara bahasa Inggris 
Rekapitulasi persentase ketuntasan mahasiswa dalam berbicara bahasa Inggris pada siklus I dan siklus II. Pada diagram 3 diatas, Siklus I diperoleh hasil sebesar $45 \%$ mahasiswa yang tuntas dalam pembelajaran kemampuan berbicara dengan menggunakan Platform Learnsocial, dengan mahasiswa sebanyak 9 orang. Sedangkan 55\% mahasiswa belum tuntas dalam pembelajaran kemampuan berbicara dengan Platform Learnsocail dengan mahasiswa sebanyak 11 orang. Nilai rata-rata yang diperoleh adalah 71,3. Pada Siklus II diperoleh hasil sebesar 90\% mahasiswa yang tuntas dalam pembelajaran kemampuan berbicara dengan Platform Learnsocial dengan mahasiswa sebanyak 18 orang, sedangkan $10 \%$ mahasiswa tidak tuntas dalam pembelajaran kemampuan berbicara dengan mahasiswa sebanyak 2 orang. Nilai rata-rata siklus II adalah 88,5. Hal ini membuktikan bahwa menngunakan Platform learnsocial dapat meningkatkan kemampuan berbicara mahasiswa Prodi Pendidikan Bahasa Inggris T.A 2019/2020. Pada Platform Learnsocial, dosen dapat memberikan review/ulasan serta nilai kepada mahasiswa. Mahasiswa dapat mengeksplor kemampuan berbicaranya dengan platform learnsocial. Selain kemampuan berbicara atau speaking skill mahasiswa dapat melatih kemampuannya yang lain seperti structure dan grammar (tata bahasa), keakuratan pronunciation (pengucapann), writing skill (kemampuan menulis), listening skill (kemampuan mendengar). Selain itu platform learnsocial dapat mudah untuk digunakan selain menggunakan laptop atau komputer dapat juga menggunakan handphone. Pada Platform learnsocial dapat mengintegrasikan komunikasi sehari-hari dengan materi (courses) yang ada dalam platform tersebut.

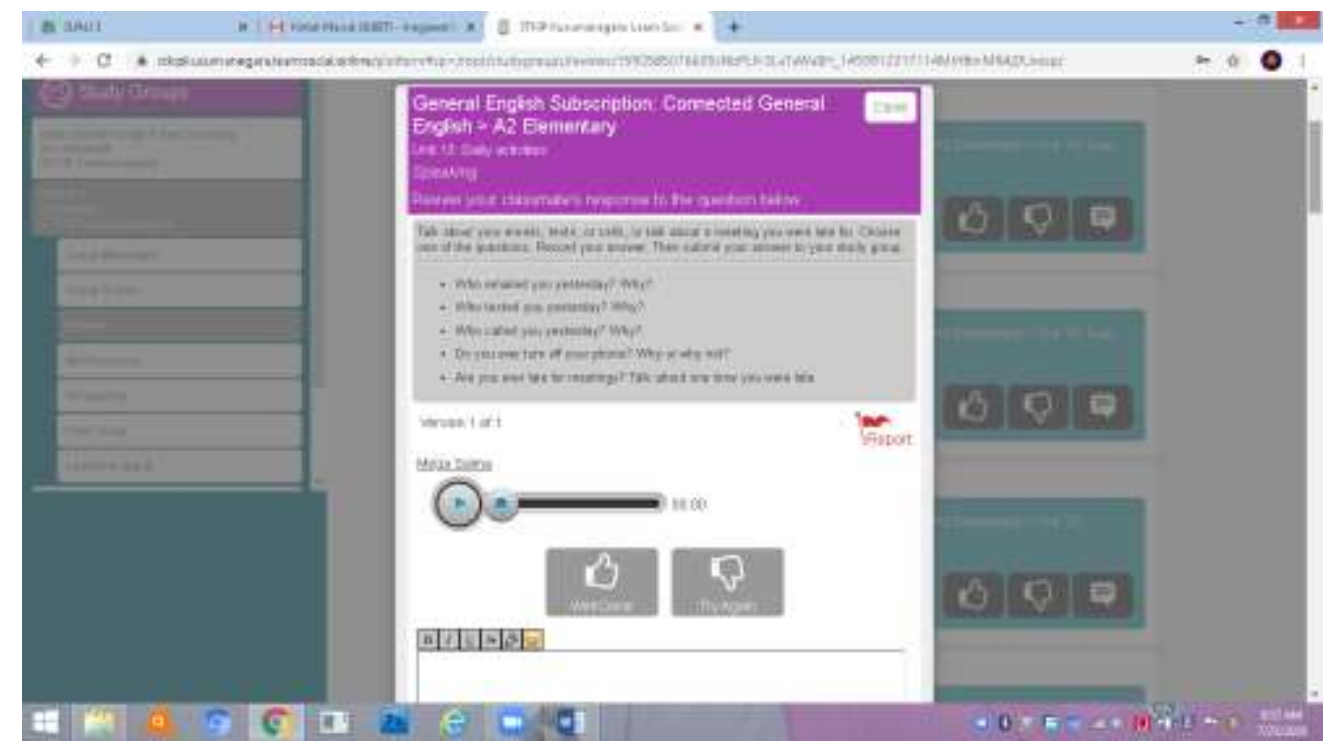

Sumber : Peneliti

Gambar 1.

Preview Platform Learnsocial I

Berikut adalah tampilan Platform Learnsocial untuk mengukur kemampuan berbicara mahasiswa. Mahasiswa dapat merekam kemampuan berbicaranya dengan mengklik tombol sambil berbicara. Setelah selesai, dosen dapat langsung memeberikan ulasan atau mereview rekaman kemampuan berbicara mahasiswa serta memberikan nilai. 


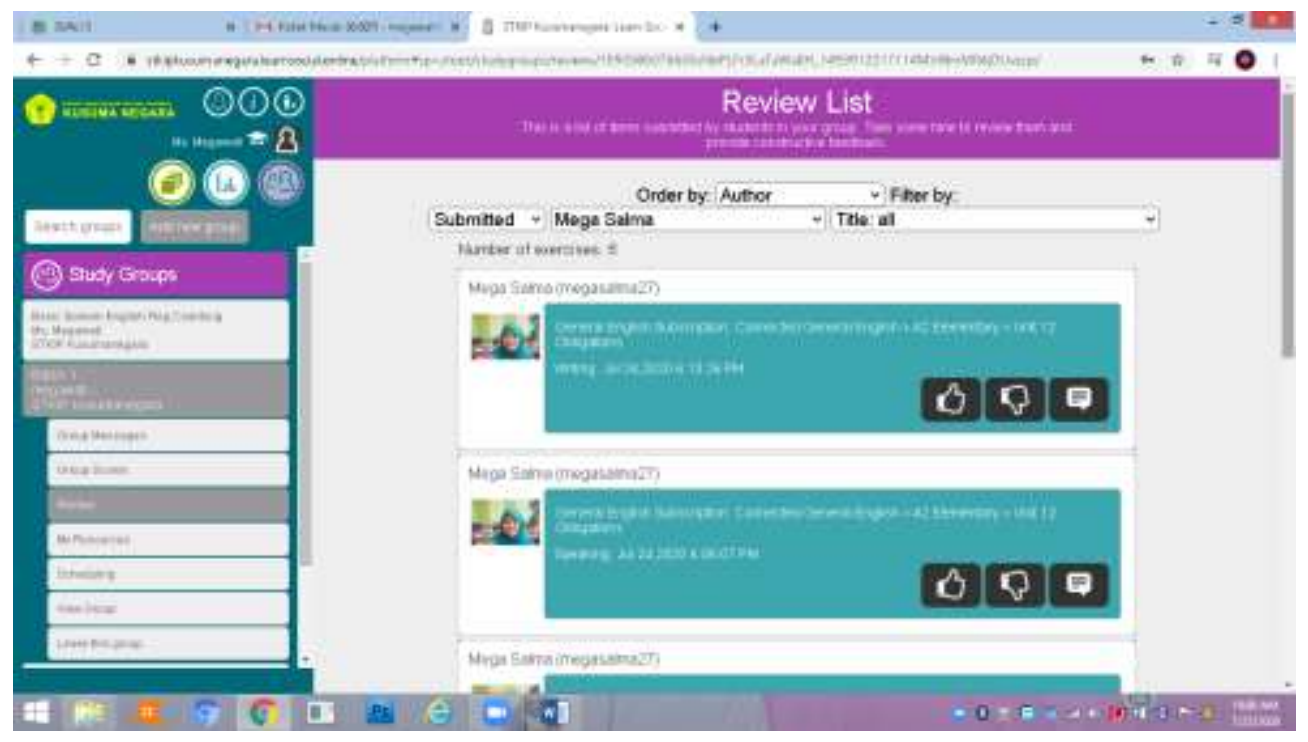

Sumber : Peneliti

Gambar 2.

Preview Platform Learnsocial II

Pada tampilan platform di atas, adalah mahasiswa yang telah menyelesaikan tugasnya/ menyerahkan tugas maka kotak masih berwarna biru, yang artinya dosen masih belum mengecek, memberikan review serta nilai ke mahasiswa.

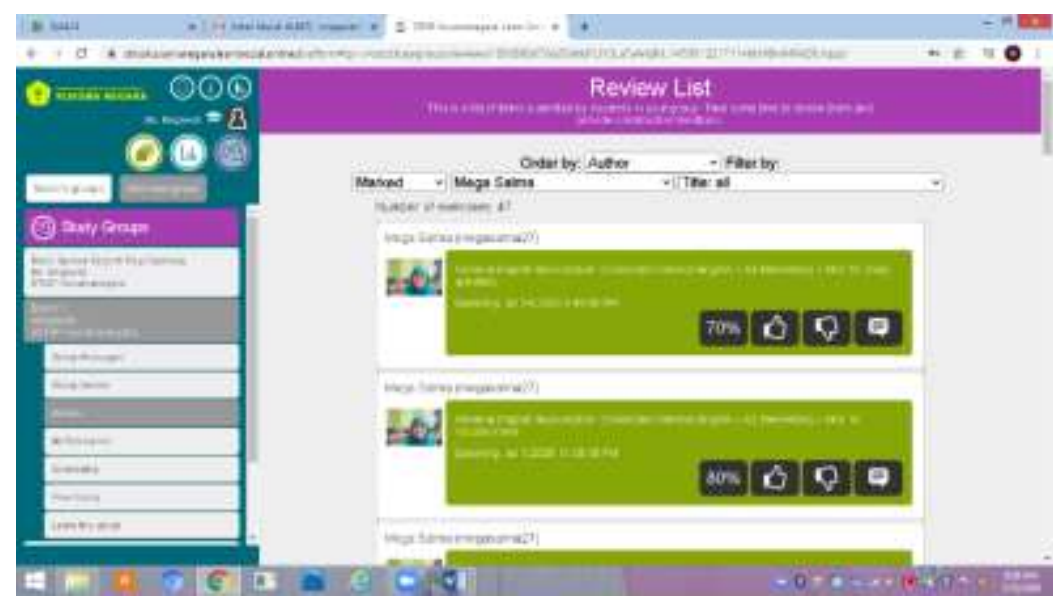

Sumber : Peneliti

Gambar 3.

Preview Platform Learnsocial III

Pada tampilan di atas, dosen telah mengecek tugas mahasiswa serta memberikan nilai sehingga kotak yang semula berwarna biru berubah menjadi hijau muda. 


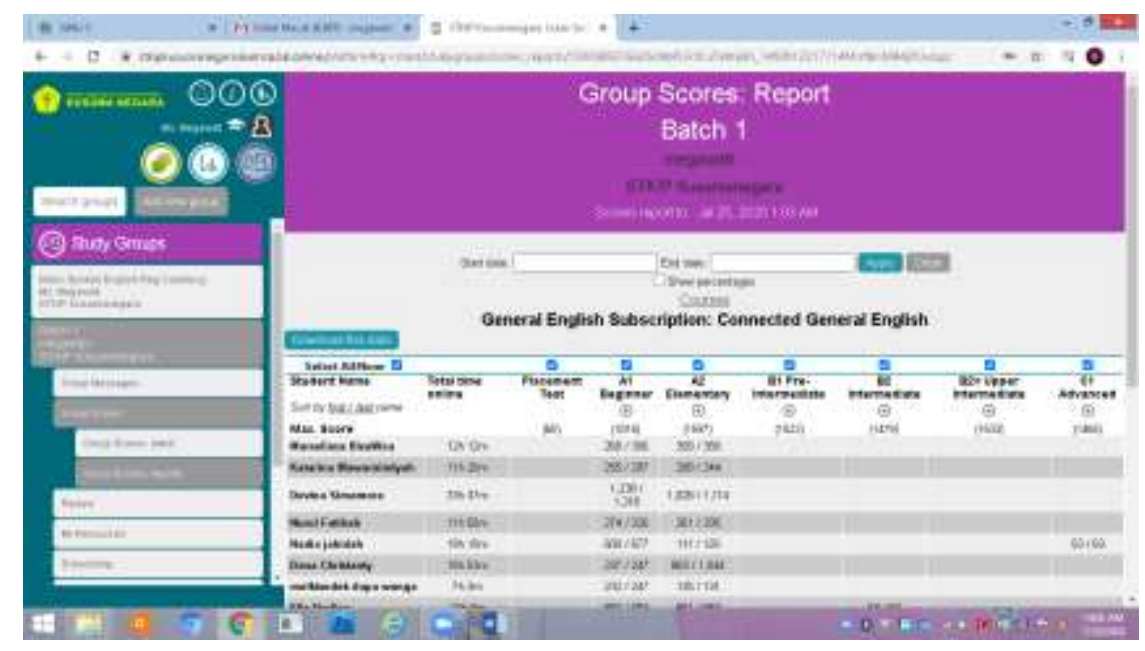

Sumber : Peneliti

\section{Gambar 4. \\ Preview Platform Learnsocial IV}

Ini adalah tampilan nilai secara keseluruhan dari tiap level pada Platform learnsocial.

Kekurangan dalam penggunaan Patform Learnsocial:

1. Fitur learnsocial yang sering error

Kejadian error tersebut bisa disebabkan karena jaringan internet yang tidak stabil, mahasiswa lebih banyak yang menggunakan handphone daripada laptop saat merekam kemampuan berbicara. Selain itu posisi ketika merekam dapat mempengaruhi sinyal yang menyebabkan proses perekaman yang sering dilakukan berulang-ulang karena gagal dalam penyimpanan,

2. Penggunaan kuota internet

Dibutuhkan kuota internet yang cukup untuk dapat memudahkan dalam proses perekaman audio.

3. Memiliki batas waktu penggunaan

Menurut Megawati (2019:51) Platform learnsocial merupakan jenis platform berbayar. Platform tersebut hanya dapat berlaku selama setahun, setelah lewat dari satu tahun maka materi tidak dapat diakses

\section{CONCLUSION}

Berdasarkan hasil penelitian peningkatan kemampuan berbicara dengan platform learnsocial maka didapatkan hasil bahwa platform learnscocial dapat dijadikan media dalam pembelajaran bahasa Inggris. Platform tersebut merupakan berbayar yang setiap mahasiswa dapat menggunakannya selama satu tahun. Mahasiswa dapat melihat skor ataupun nilai dalam platform learnsocial setelah mereka mengerjakannya. Pada siklus I diperoleh 45\% ketuntasan kemampuan berbicara mahasiswa dengan nilai rata-rata 71,3. Pada siklus II diperoleh $90 \%$ ketuntasan kemampuan berbicara mahasiswa dengan niai rata-rata 88,5. Dengan menggunakan Platform learnsocial diharapkan dosen, guru serta tenaga pengajar akan mudah menyampaikan materi sehingga waktu yang digunakan dalam pembelajaran dikelas dapat efektif. Mahasiswa dapat melatih kemampuan berbicaranya sendiri dengan mengakses learnsocial. Mahasiswa dapat mengasah kemampuannya karena dalam platform tersebut memiliki tingkatan level yang berbeda- 
beda dan dari yang dasar atau beginner sampai yang advanced. Setelah mahasiswa mengerjakan latihan-latihan yang ada dalam platform tersebut, mereka dapat melihat score/nilai yang secara otomatis muncul selain score atau nilai yang diberikan dosen.

\section{REFERENCES}

Arikunto, S. (2014). Prosedur Penelitian Suatu Pendekatan Praktik. Jakarta: PT Rineka Cipta.

Brown, H. D. (2004). Language Assessment: Principles and Classroom Practices. New York: Pearson Education.

Guilan, H. (2017). Peningkatan Keterampilan Bercerita Dengan Menggunakan Media Boneka Tangan Pada Siswa Kelas IX.1 SMP Negeri 3 Pujut Kab. Lomnok Tengah Tahun Pelajaran 2016/2017. JUPE, Vol 2 No.2.

Kariani, Vitta. (2017). Peningkatan Keterampilan Berbicara Melalui Model Pembelajaran Kooperatif Tipe Artikulasi Pada Siswa Kelas VI SD Inpres 3 Talise. E-Journal Bahasantondea, Vol. 4 No. 2.

Megawati \& Eka Rista. (2020). Penerapan platform learnsocial dalam keterampilan bahasa Inggris mahasiswa. Jurnal Ilmiah Pena: Sains dan Ilmu Pendidikan. Available at: 〈http://ojs.stkippi.ac.id/index.php/jip/article/view/229>.

Megawati, M. (2017). Pengaruh Media Poster Terhadap Hasil Belajar Kosakata Bahasa Inggris. (Eksperimen di SDIT Amal Mulia Tapos Kota Depok). Getsempena English Education Journal, 4(2).

Munir. (2010). Kurikulum berbasis teknologi Informasi dan Komunikasi. Bandung: Alfabeta

Pandaleke, Alex, dkk. (2017). Upaya Meningkatkan Keterampilan Berbicara Melalui Metode Bermain Peran Pada Sisa Kelas V SD Bala Keselamatan Palu. Bahasantondea.

Ramdayana, I.P., Prasetyono, H., \& Rahman, N.V.T. (2020). Comparative Study Of Discussion And Question-Answer Learning Method To Improve Learning Outcomes Of Vocational High School Students. Jurnal PAJAR (Pendidikan dan Pengajaran), 4(3), 597-607. DOI : http://dx.doi.org/10.33578/pjr.v4i2.7990.

Saputra, S., \& Prasetyono, H. (2020). The Effect of Scientific Approach to the Activity of Learning Students in SMPN 25 Tangerang City. Jurnal PAJAR (Pendidikan Dan Pengajaran), 4(1), 20-30.

Sadiman, Arief S, dkk. (2008). Media Pendidikan Pengertian Pengembangan dan Pemanfaatannya, Jakarta: PT. Raja Grafindo Persada. 